the comparative harmlessness of submarine disturbances as it lies across the main series of transAtlantic cables.

The re-sounding of the ocean around the epicentral area of the Cabot Channel earthquake may be expected to reveal instructive changes in depth.

4 Park Quadrant, Glasgow, C.3.

J. W. Gregory.

\section{Method of Determining the Position of the} Symmetry Axis of a Crystal by means of X-Rays.

A NARRow beam of $\mathrm{X}$-rays, passing through the same point of a thin plate of a crystal, and moving in such a way that it successively occupies all the possible positions within a definite solid angle, will have Bragg's reflections from the atomic planes in the crystal. Their traces on a photographic plate, which is fixed relatively to the crystal, will give a sequence of lines the form and position of which will depend on the position of the reflecting planes and also on the constants of the crystal lattice.

If the axis of symmetry of the crystal lies within the space angle described by the ray, and if it makes a small angle with the perpendicular to the photographic plate, then on the latter will appear a series of hyperbolæ, symmetrically situated, as may be seen on the photograph (Fig. 1). If the orientation

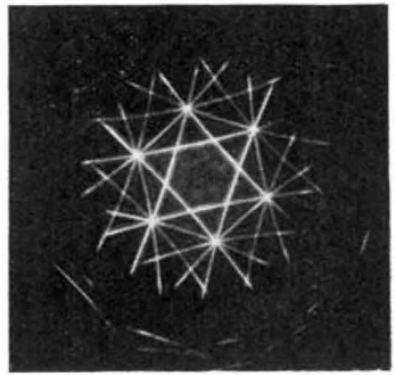

FIG. 1.-Quartz.

of the crystal in relation to the photographic plate is known, the position of the axis in the crystal may be found, and some data may be obtained regarding its structure.

The above-mentioned scheme was realised in the following manner : a system consisting of a rigidly connected photographic plate and a small crystal, placed at a distance of $17 \mathrm{~mm}$. in front of the plate, slowly rotated round the horizontal line passing through the crystal and perpendicular to the plate, and oscillated round a vertical axis which also passed through the crystal intersecting the first one. A horizontal beam of rays emitted by the target of a Röntgen tube passes through a pin-hole placed close before the crystal, through the point of intersection of both axes of rotation, and then is stopped by a small fixed screen situated in front of the photographic plate. This screen prevents the blackening of the plate by the undeflected beam and thus only reflected rays strike the plate and give the above-mentioned picture. The diagrams thus obtained are equivalent to the ' $P$-patterns' with an electron beam described by Kikuchi (Japanese Journal of Physics, vol. 5, No. 2).

It is obvious that the same picture will be obtained by means of a wide cone of rays emitted from a large radiating surface and passing through the abovementioned pin-hole. In this case it is not necessary to rotate the plate and the crystal, but the blackening of the plate, caused by undeflected rays, spoils the photographs.

Optical Institute, Leningrad, Oct. 9.
Weitere Beobachtungen über die Dissymmetrie der Emission von Serienlinien.

AN einer früheren Stelle dieser Zeitschrift (NatuRE, Juli 27,1929 , p. 125) habe ich eine kurze vorläufige Mitteilung über die neue Erscheinung der Dissymmetrie der Lichtemission im elektrischen Feld veröffentlicht. Im Folgenden seien kurz die Ergebnisse weiterer Beobachtungen über diese Erscheinung mitgeteilt.

Wie ich in meiner Schrift über die Axialität der Lichtemission und Atomstruktur (Polytechnische Buchhandlung A. Seydel, Berlin, 1927) dargelegt habe, stellen die im elektrischen Feld erscheinenden Komponenten der Linien des Wasserstoffatoms Linienserien von bestimmter Charakteristik dar. Von diesen Wasserstoffserien habe ich auf ihr Verhalten in der neuen Erscheinung folgende Linien untersucht : von der Serie $2 s-m p^{2}$ die Linien $3 p^{2} \mathrm{H}_{\alpha} \pm 1,4 p^{2} \mathrm{H}_{\beta} \pm 6$, $5 p^{2} \mathrm{H}_{\gamma} \pm 13$; von der Serie $2 p^{2}-m d^{3}, f^{3}$ die Linien $4 d^{3}, f^{3} \mathrm{H}_{\beta} \pm 4,5 d^{3}, f^{3} \mathrm{H}_{\gamma} \pm 10$; von der Serie $2 s-m p^{4}$ die Linien $4 p^{4} \mathrm{H}_{\beta} \mp 2,5 p^{4} \mathrm{H}_{\gamma} \pm 3$; von der Serie $2 p^{2}-m d^{5}, f^{5}$ die Linie $6 d^{5}, f^{5} \mathrm{H}_{\delta} \pm 6$, von der Serie $2 s-m p^{6}$ die Linie $6 p^{6} \mathrm{H}_{\delta} \mp 2$. Von allen diesen Linien werden diejenigen, welche vom elektrischen Feld nach Rot verschoben werden, längs der Achse des Feldes entgegengesetzt zur Feldrichtung intensiver emittiert als in der Feldrichtung. Umgekehrt werden diejenigen Linien, welche vom elektrischen Feld nach Violett verschoben werden, längs der Feldachse in der Feldrichtung intensiver emittiert als entgegengesetzt dazu.

Aus dem Spektrum des Heliums habe ich folgende Linien auf ihr Verhalten in der neuen Erscheinung untersucht und zwar in der Achse des elektrischen Feldes wie auch in einer $45^{\circ}$ dazu geneigten Achse : für Orthohelium von der Serie $2 s-m p^{2}$ die Linie $3 p^{2}$ $\lambda 3889$, von der Serie $2 p^{2}-m s$ die Linien $4 s \lambda 4713$ und $5 s \quad \lambda 4121$, von der Serie $2 p^{2}-m d^{3}, f^{3}$ die Linie $3 d^{3}, f^{3}$ $\lambda 5876$, von der Serie $2 p^{2}-m d^{3}$ die Linie $4 d^{3} \lambda 4472$, von der Serie $2 p^{2}-m f^{3}$ die Linie $4 f^{3} \lambda 4469$, von der Serie $2 p^{2}-m f^{5}$ die Linie $5 f^{5} \lambda 4025$, von der Serie $2 p^{2}-m p^{2}$ die Linie $4 p^{2} \lambda 4519$; für Parahelium von der Serie $2 S-m P^{2}$ die Linien $3 P^{2} \lambda 5016$ und $4 F^{2}$ $\lambda 3965$, von der Serie $2 P^{2}-m D^{3}, F^{3}$ die Linie $3 D^{3}, F^{3}$ $\lambda 6678$, von der Serie $2 P^{2}-m D^{3}$ die Linie $4 D^{3} \lambda 4922$. Alle diese Heliumlinien folgen in der neuen Erscheinung derselben Gesetzmässigkeit wie die Wasserstofflinien ; es werden nämlich diejenigen Linien, welche vom elektrischen Feld nach Rot verschoben werden, entgegengesetzt zur. Feldrichtung intensiver emittiert ; dagegen werden diejenigen Linien, welche vom Feld nach Violett verschoben werden, in der Richtung des Feldes intensiver emittiert.

Die ausführliche Mitteilung über die vorstehenden Beobachtungen wird voraussichtlich in den Annalen der Physik erscheinen. Im Anschluss an sie werde ich die wichtigen theoretischen Folgerungen darlegen, die sich aus ihnen ziehen lassen.

Grosshesselohe-München, Nov. 18.

J. STARK.

\section{Chemical Biogenesis and the Development of Secretion Cells.}

Among the Research Items in Nature of Sept. 14, 1929 , p. 426 , is a note upon an interesting paper recently published by Prof. John Read on "Some Biogenetic Relationships in the Menthone Series ".

At the end of the paper referred to in the note (Chemistry and Industry, vol. 48, No. 32, p. 786 ; 1929) Prof. Read says: "The excessively delicate control of molecular transformation which is here implied appears to be a prerogative of the living organism. The organic chemist is powerless to effect such subtle differentiations by artificial means. At the present stage of our knowledge the finer mani- 